琵琶湖および河川の水生生物の生息状況調査 Survey of the State of Aquatic Organisms in Lake Biwa and it's Surrounding Rivers

\author{
井出充 彦 * \\ Atsuhiko IDE *
}

ABSTRACT: In the fishing industry, in order to manage fishing resources effectively, it is important to adopt measures for aquatic resources based on an understanding of the current ecological conditions of an area. To help in this regard, we as the staff of the Shiga Prefecture Fisheries Experiment Station collected and surveyed fish and crustaceans from Lake Biwa and it's surrounding rivers in 1994. We could confirm the existence of most of the fish and crustaceans in Shiga Prefecture; however, it is feared that the ecosystems in these waters are changing. According to our study, depending on the area surveyed, we found that there was a small population of several species while there was an increase in population of other species which were normally fewer. Furthermore, we found that a diverse environment is essential for a variety of species to co-exist.

KEYWORDS: AQUATIC ORGANISMS, LAKE BIWA, DIVERSE ENVIRONMENT

\title{
1. 調査の目的
}

漁業において限られた資源を有効かつ永続的に利用するためには、漁業対象魚種とその他の魚種との関わ りや環境との関わりを考慮した上で、水産資源対策等の行政施策を実施するのが望ましい。それは特に内水 面のような限られた水域において重要である。

そこで滋賀県水産試験場では、琵琶湖をはじめとする、滋賀県下の内水面漁業の基盤となる水域の生態学 的現況を把握し行政施策の基礎資料とするため、琵琶湖および河川の水生生物の生息把握調査を実施してい る。1993年度の予備調査を経て、1994年度は琵琶湖とその周辺の内湖(元来琵琶湖の一部であったものが何ら かの理由で独立してできた湖）および主要河川において、魚類と甲殸類（十脚目）の採集調査を行い、1995 年度は1994年度に確認されなかった魚種の確認調査（以下補完調査）と琵琶湖沿岸部の底生生物調査や環境 調査を行っている。本報では1994年度の調査結果の概要と得られた若干の知見について報告する。

なお、この報告は滋賀県水産試験場の全技術職員が行った調査に基づき、著者がとりまとめたものでる。

\section{2. 調査の概要と結果}

調査地点は、滋賀県下を北部、東部、東南部、南部、西部の5区域に分け、各区域ごとに河川上·中・下流、 内湖、琵琶湖沖合・沿岸について設定した（合計42地点）。主な調査地点は河川は姉川、愛知川、野洲川

* 滋賀県水産試験場 Shiga Prefecture Fisheries Experiment Station 
大戸川、安昙川の上・中・下流（支流含む）および瀬田川中流、石田川上流、内湖は余呉湖（簃密には内湖 ではないが、ここでは便宜的に内湖として扱う）、伊庭内湖、西の湖、柳平湖、堅田内湖、琵琶湖沿岸は各 区域地先、琵琶湖沖合は南部を除く各区域沖合で、さらに必要に応じ細かい調查地点を設定した。

1994年4月から1995年3月の期間中、琵琶湖においては4回、内湖、河川においては2回を目標に調査を行った。 採集方法は、河川においては調查用エレクトリック・ショッカー、投網など、内湖においては小型定置網 を主に使用した。琵琶湖においては沿岸は手繰りの小型底曳き網と小型定置網を主に使用し、また、えり （定置網漁業の一種）漁業者から標本の提供を受けた。沖合は漁船(侓船)による底曳き網を使用した。採捕 された魚類は標本として必要な量のみ持ち帰り、その他は原則として計数の上放流した。

今回の調查の結果、過去に滋賀県下で確認された 70 種の魚類（亜種含む）と 7 種の甲殼類（十脚目）のう

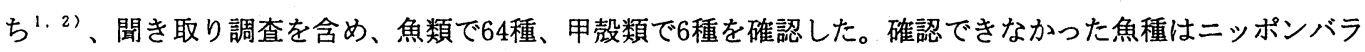
タナゴ Rhodeus ocellatus smithi、アユモドキ Leptobotia curta、ヤマメ Oncorhynchus masou masou、カ ワバタモロコ Aphyocypris rasborella、カワヒガイ Sarcocheilichthys variegatus variegatus 、アオウ オ Ctenopharyngodon piceusの6種であった。

魚類相は、内湖以外の調查区分ではおおむね区域間の差は見られなかった。河川上流ではタカハヤ Phoxinus oxycephalus、カワムツ Zacco temmincki、カジカ Cottus pollux、アマゴ Oncorhynchus masou macrostomus、イワナSalvelinus leucomaenisなどが、河川中下流ではオイカワ Zacco platypus、ヨシノボ リRhinogobius sp.OR、アユ Plecoglossus altivelis altivelis、アブラハヤ Phoxinus lagowski steindachneriなどが、琵琶湖沿岸ではアユ、ヨシノボリ、ゼゼラ Biwia zezera、デメモロ Squalidus japonicus japonicus、ブルーギル Lepomis macrochirusなどが、沖合ではデメモロコ、ハスOpsariichthys uncirostris uncirostris、ヨシノボリ、ゼゼラなどが普通に見られた。

なお、河川中流ではふつうに見られた魚種以外に野洲川ではイトモロコ Squalidus gracilis gracilis、 ズナガニゴイ Hemibarbus longirostrisといった滋賀県では生息域の限られた魚種 ${ }^{32}$ 、普通琵琶湖に生息 しているスゴモロコSqualidus chankaensis biwaeが見られた。また安是川でもイトモロコの生息が確認さ れた。その他、全ての河川下流と姉川中流において、近年琵琶湖で多く見られるようになったヌマチチブ Tridentiger kuroiwaebrevispinisの生息が確認された。

内湖では調查した 5 カ所でそれぞれ特徵的な魚類相の違いがみられた(後述)。また、伊庭内湖および西の 湖ではアメリカザリガニProcambarus clarkiiが多数見られた。

\section{3. 考察}

(1) 今回の調査で得られた若干の知見

\section{1) 魚類相について}

1994年度の調査で確認されなかった魚種は、すでに滋賀県では絶减したとされるアユモドキとニッポンバ ラタナゴを除いて、ヤマメ、カワバタモロコ、カワヒガイ、アオウオの 4 種であるが、このうち、前 2 種につ いては現在進行中の補完調查において、ごく限られた地点で採集しており、確認しうる魚種はほぼ確認でき たことになる。しかし、琵琶湖や内湖では、以前は多く生息していたとされるカネヒラ Acheilognathus rhombeus、イチモンジタナゴAcheilognathus cyanostigmaなどのタナゴ類やメダカOryzias latipesなどが少 数か調查地点によっては全く採捕されず、さらにこれまでほとんど採捕されなかったワカサギ Hypomesus transpacificus nipponensisが新たに放流されていないにも関わらず琵琶湖沖合で比較的多く採捕される （1994年11月21日に長浜沖で1曳網中52尾）など、琵琶湖および内湖の魚類相の変化が進行中であるものと思 われる。 
また、河川については、特に採捕個体数の少なかったものに、アカザ Liobagrus reini、ホトケドジョウ Lefua costata echigonia、ギギ Pseudobagrus fulvidraco、メダカなどがあげられ、なんらかの保護対策 の必要性が感じられた。

2) 水域の特性

河川においては、前述の通り確認された魚種には特に調査区域間の差が見られなかったが、野洲川の冬期 調査の中流域に設定した地点において、採捕魚種数が 18 種類 (フ十類を 1 種と計数) と今回の河川調査で最も多く の魚種が採捕された (表1)。この原因は、当該調査地点は減水期に生じる本流に接したやや流れのある溜まり が存在し、それが一部の魚種にとって、淀川におけるわんどと同様 ${ }^{5}$ 、、良好な生息場所あるいは越冬場所と なっていたからと思われる。溜まりと本流との採捕種数を比較すると、溜まりでは17種、本流では10種とな つている。

一方、同じく冬季調査において約 $7 \mathrm{Km}$ 下流に設定した調査地点(溜まりなし)では9種と少なく、外来性のヌ マチチブが含まれていた。採捕個体数もヨシノボリ以外は比較的少なかった(表2)。また、本流中の護岸ブロ ックの隙間で採捕される魚類のほとんどがオオクチバス Micropterus salmoides salmoidesであった。この 時採捕された13尾のオオクチバスの胃内容物を調べたところ、6尾が空胃で3尾がスジエビを4尾がヨシノボリ を1尾づつ捕食していた。同じ河川でありながら下流域の調査地点で採捕種数や採捕個体数の少ない原因は、 溜まりがなく単調な環境であることと、オオクチバスの侵入が関係していることが考えられる。

表1. 河川中流における採捕魚類数の比較 (冬季調査)

\begin{tabular}{lccc}
\hline 河川名 & 調査日 & 調査地点数 & 採捕種類数 \\
\hline 姉川 & $94 / 12 / 16$ & 1 & 12 \\
愛知川 & $94 / 12 / 21$ & 2 & 17 \\
野洲川 & $94 / 12 / 13$ & 2 & 18 \\
大戸川 & $94 / 12 / 07$ & 2 & 9 \\
瀬田川 & $94 / 12 / 19$ & 2 & 12 \\
安曇川 & $94 / 12 / 09$ & 2 & 12 \\
\hline
\end{tabular}

表2 野洲川冬季調査における調査地点ごとの採捕魚種の調査時間当たりの個体数 (No. / hr)

\begin{tabular}{|c|c|c|c|}
\hline $\begin{array}{c}\text { 魚種名 } \\
\end{array}$ & 中流溜まり & 中流本流 & 下流 \\
\hline スナヤツメ Lampetra reissneri & 2 & 0 & 0 \\
\hline ウナギ Anguilla japonica & 0 & 0 & 1 \\
\hline オイカワ Zacco platypus & 70 & 81 & 2 \\
\hline アブラハヤ Phoxinus lagowski steindachneri & 2 & 1 & 0 \\
\hline タモロコ Gnathopogon elongatus elongatus & 36 & 21 & 0 \\
\hline モツゴ Pseudorasbora parva & 2 & 0 & 0 \\
\hline カマツカ Pseudogobio esocinus esocinus & 31 & 1 & 2 \\
\hline スゴモロコ Squalidus chankaensis biwae & 23 & 0 & 0 \\
\hline イトモロコ Squalidus gracilis gracilis & 27 & 1 & 0 \\
\hline ズナガニゴイ Hemibarbus longirostris & 34 & 8 & 0 \\
\hline コイ Cyprinus carbio & 4 & 0 & 0 \\
\hline フナ類 Carassius sp. & 39 & 12 & 1 \\
\hline ヤリタナゴ Tanakia lanceolata & 1 & 0 & 0 \\
\hline タイリクバラタナゴ Rhodeus ocellatus ocellatus & 7 & 0 & 0 \\
\hline シマドジョウ Cobitis biwae & 4 & 1 & 0 \\
\hline ギギ Pseudobagrus fulvidraco & 1 & 0 & 0 \\
\hline ナマズ Silurus asotus & 3 & 0 & 0 \\
\hline オオクチバス Micropterus salmoides salmoides & 0 & 0 & 16 \\
\hline ドンコ Odontobutis obscura obscura & 0 & 1 & 0 \\
\hline ヨシノボリ Rhinogobius sp. OR & 17 & 3 & 40 \\
\hline ヌマチチブ Tridentiger kuroiwae brevispinis & 0 & 0 & 1 \\
\hline ウキゴリ Chaenogobius urotaenia & 0 & 0 & 1 \\
\hline ウツセミカジカ Cottus reinii & 0 & 0 & 6 \\
\hline
\end{tabular}


内湖では、各湖で採捕魚種相 (合計28種)にはっきりした違いが見られたが、魚類相によって便宜的に分類 すると、余呉湖の増殖事業型、伊庭内湖および西の湖の多種共存型、柳平湖、堅田内湖の亳種優占型に分け られる(図1).

余吳湖 (面積1.7k $\mathrm{km}^{2}$ )においてはワカサギ、ホンモロコ Gnathopogon caerulescensなどの増殖事業が行われ ており、それらが今回の調査結果に反映している。ここでも河川下流と同様、多数のヌマチチブ（増殖対象 外）の生息が確認されたが、これは、琵琶湖からの揚水が行われていることによると思われる5゙。

多種共存型の伊庭内湖 (主要部面 積0. $5 \mathrm{~km}^{2}$ ) 及び西の湖 (面積 $2.9 \mathrm{~km}^{2}$ ) では、湖岸のほぼ全域にヨシなど抽 水植物が群生して、産卵場所や稚魚 の生息場所が確保されており、さら にそれぞれ3本以上の流入河川があ ることが、多くの魚類にとって生息 に適した複雑な環境を作り出してい るものと思われる ${ }^{6)}$ 。さらに、とも に水門を隔てて琵琶湖と通じており、 水門が閉められる減水時以外は魚類 が琵琶湖と行き来できるなどの条件 が一致している。これらが多魚種が 共存している原因であると考えられ る。

ブルーギルとオオクチバスによる 塞種優占型の柳平湖 (主要部面積0. $05 \mathrm{~km}^{2}$ ) では、流入河川は細い農業用 水路1本のみで、流出側も琵琶湖と 通じているが、堰のため魚類の行き 来は不可能であり、ほぼ閉鎖された 止水域といえる。この湖の周囲には ヨシなどの抽水植物帯があり、古く からこの湖を利用している淡水真珠 養殖業者によると、かつてはタナゴ やフナ類が多数生息していたとのこ
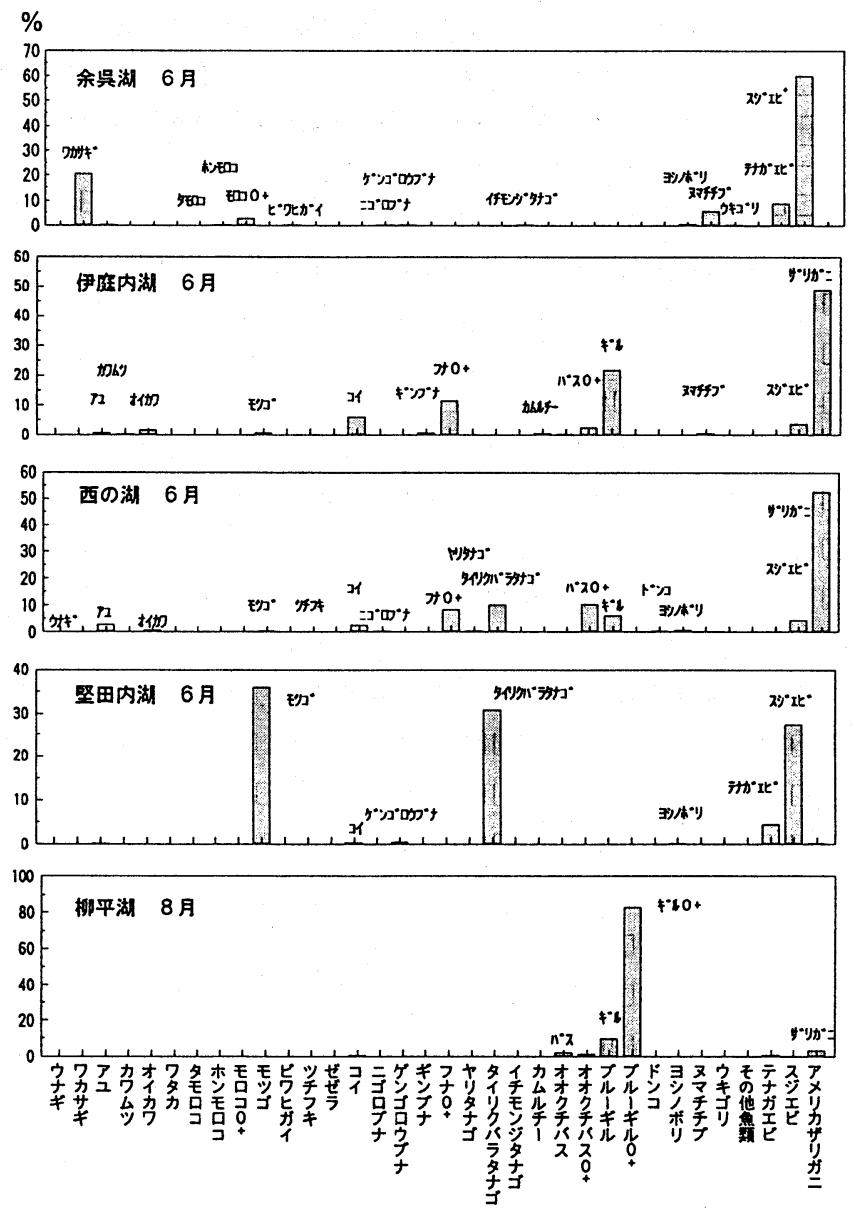
とである。しかし、このような比較 的狭く単純な閉鎖水域では一旦才オ クチバスとブルーギルが侵入した場

図1 内湖における採集魚類の個体数頻度

合、抽水植物帯を生活の場として利用していた他の在来種はほとんど駆逐されてしまうようである。

一方、柳平湖と同様閉鎖水域で朞種優占型の堅田内湖 (主要部面積0.08 $\mathrm{km}^{2}$ ) は、住宅地に囲まれた小さな湖 で、西側の湖岸の大部分がコンクリート化され、抽水植物帯は南端及び北端を中心に少量残されているのみ ある。さらに家庭排水流入による水質污染により、フナやホンモロコなどの多くの漁業対象魚種にとっては 繁殖に適した環境であるとは言い難い。ここでは、タイリクバラタナゴ Rhodeus ocellatus ocellatusとモ ツゴ Pseudorasbora parvaが優占種となっているが、タイリクバラタナゴは二枚貝に、モツゴは棒状の障害 物（植物を含む）などに産卵し、特に抽水植物が無くても産卵場所は確保できるものと思われ、また両種と 
も水質悪化に強く、それらが優占種となり得る原因であると考えられる。また、オオクチバス(目視のみ)、 ブルーギルは他の内湖と同様の侵入状況にあると思われるが、個体数が少くなっている理由としては、家庭 排水流入により底質が厚い腐泥となっており、砂地を好んで産卵床を作る当該魚種の産卵場所としては適さ ないためと思われる。

(2) 今後の水産資源対策について

野洲川および内湖の例から、此水域と流水域が共存し抽水植物帯が豊富なことなど、より複雑で多くの魚 種にとっての産卵繁殖場が確保されている水域ほど多様な魚類相を維持することができるものと想像できる。 全ての水面においてオオクチバス、ブルーギルなどの外来魚や水質変化の影響を最小のものとし、主要魚 種の資源対策を効果的なものとするためにも、多様な環境を残しあるいは新たに創造し、環境収容力・再生 産力を高める努力が重要と思われる。

今後水域の環境変化の指標とするため、今回の調査で判明した各水域の魚類相が今後どのように変化して 行くか長期的に追跡する必要があるものと思われる。

4. 文献

1)滋賀県琵琶湖文化館編(1991)：湖国びわ湖の魚たち, 滋賀県立琵琶湖文化館, 滋賀.

2) 滋賀県水産課編（1994）：滋賀の水産, 88-93, 滋賀県, 滋賀

3) 前畑正善・藤本勝行・吉田雅澄 (1994)：滋賀県下のズナガニゴイとイトモロコの新分布地, 滋賀県立文化館 紀要, (12), 21-22.

4) 矢田敏晃・加藤喜久也 (1987)：淀川の魚類相と生息状況, 大阪府淡水魚試験場研究報告, (9), 119-122.

5) 里内勝 (1991)：余吳湖の水質, 滋賀県の自然誌, 1879-1899, (財) 滋賀県自然保護財団, 滋賀

6)里内勝 (1991)：西の湖の水質と物質収支, 滋賀県の自然誌, 1901-1924，(財)滋賀県自然保護財団, 嵫賀. 